\title{
Print or Electronic, Reading Is Indispensable: Case of Ibeku High School Umuahia Abia State
}

\author{
Joy C. Onyenachi' ${ }^{1}$, Edward C. Amadi ${ }^{2}$, Ogechi O. Awa ${ }^{3}$ \\ ${ }^{1}$ Michael Okpara University of Agriculture, Umudike, Nigeria \\ ${ }^{2}$ Collection Development Department, Michael Okpara University of Agriculture, Umudike, Nigeria \\ ${ }^{3}$ Department of Library and Information Science, Michael Okpara University of Agriculture, Umudike, Nigeria \\ Email: onyenachijoy@gmail.com, edwardamadi50@gmail.com
}

How to cite this paper: Onyenachi, J.C., Amadi, E.C. and Awa, O.O. (2019) Print or Electronic, Reading Is Indispensable: Case of Ibeku High School Umuahia Abia State. Open Access Library Journal, 6: e4824. https://doi.org/10.4236/oalib.1104824

Received: August 3, 2018

Accepted: January 21, 2019

Published: January 24, 2019

Copyright $\odot 2019$ by author(s) and Open Access Library Inc.

This work is licensed under the Creative Commons Attribution International License (CC BY 4.0).

http://creativecommons.org/licenses/by/4.0/

\section{Abstract}

The study examined reading of Print and Electronic information materials among senior secondary school students of Ibeku High School Umuahia Abia State Nigeria. Literature review focused on identification of reading materials in school library of Ibeku High school, the student's reasons for reading, and challenges that affect student's reading. The research design used in this study is descriptive survey. The population is 430 which is the entire senior secondary students (one 225 and two 205) respectively. Total sample size of 172 was drawn which is $40 \%$ of the total population. 172 copies of questionnaires were administered and 164 copies returned which represent $95.3 \%$ return rate. The result was analyzed using tables and simple percentage. The findings of the research revealed that school text books are the major library collection 108 (65.9\%). Others are magazine 4 (2.4\%), Newspapers 16 (9.8\%), Electronic information materials $4(2.4 \%)$. Reasons for reading reveal the following: To develop communication skill 116 (70.7\%). Personal research for self development had 104 (63.4\%), to pass examination 85 (51.8\%). Among challenges to reading major one the students indicated was lack of personal reading materials 103 (62.8\%). From the findings it was obvious that reading culture for pleasure and self development cannot be achieved because the print and non print materials for such are not available. The study made the following recommendations as possibilities in equipping school library with print and electronic information materials: The government being owner of public schools should be committed in funding the school library as well as directly sending print and non print information materials to schools. Teaching and learning are not done in vacuum school principals and teachers should not be less concerned in equipping the school library. They should make the government realize the need for learning materials which include print electronic books and audio visual materials. School administrators should solicit for as- 
sistance from parents through the parent teacher forum; the school administrators should as well contact donors to assist; public libraries by their mandate caters for the information need of the entire citizen to which secondary school teachers and students are among. The school administrators should contact the public library to come to their aid because public libraries' mandate covers provision of information materials to public schools.

\section{Subject Areas}

Education, Sociology

\section{Keywords}

Print, Electronic, Reading, Indispensable

\section{Introduction}

In this twenty first century mentioning reading to many Nigerians who are technologically (Internet) literate seems as if one is in an obsolete generation. With this mind set reading culture keeps going down the pit. The grammatical accuracy in the language(s) keeps fizzling out while slang, unconventional short hands and jargon are fast taking over. Suggesting teaching reading receives look as though one should not retard to forgotten generation because the current era is electronic (e-era)/virtual/paperless. These are the popular expressions that address information acquisition/dissemination and utilization in the twenty first century. The generation that are taught well in reading and through reading needs to rise to the challenge of teaching reading as to correct the anomaly. Whether one is reading print or electronic document reading is reading in whatever language the information is documented.

Reading is an attempt to absorb the thought of an author and understand what that author is conveying. The author's thought could be documented in print or non-print format. Ability of an individual to read leads to ability to speak, communicate even non-verbally as well as create innovative ideas to solve problem. Reading is not only meant for success in examination, it enhances one's participation and effectiveness in socio economic and political involvement. Awa (2017) [1] citing Osundare emphatically remarks that a country's level of development is a function of her level of mental and cultural evolution as well as the state of her educational advancement; reading is essential for this achievement. Tella and Akande (2007) [2] assert that the ability to read is at the heart of self-education and lifelong learning and that is an act capable of transforming life and society. Reading culture describes the integrated pattern of reading behavior, practice, belief and knowledge. Ose in Awa (2017) asserts that the best time to build reading culture is when the child is still very young starting from identification of pictures, to reading aloud to the child and introducing the child to printed and electronic books. 


\section{Statement of the problem}

Whether print or electronic, information materials for teaching, learning, and other needs are documented more in reading format than visual. With the unequivocal benefit of reading for quality academic attainment the phobia for reading is in the increase as one observes the rate pupils and students prefer viewing to reading. The purpose of this research is to correct the current understanding that use of electronics makes reading outdated method for information acquisition hence the research is entitled Print or Electronic, Reading is Indispensable. Whether the document is in print or electronic format the major method of gaining information/knowledge from the documented format is reading. Using Ibeku High School in Abia State Nigeria as a case the research intends to find out the student's commitment to reading for academic excellence and self development for lifelong learning. Preliminary interview revealed that no study has been conducted on the topic in the intended place of study. The main research questions are: What are the reading materials (print and electronic) in school library of Ibeku High school; What are the student's reasons for reading; What are the challenges that affect student's reading and What are the possible solutions to the challenges.

\section{Objectives of the study are to:}

Identify reading material (print and electronic) in school library of Ibeku High school;

Identify the student's reasons for reading;

Ascertain challenges that affect student's reading;

Proffer solution to the challenges.

\section{Literature review}

\section{Why read?}

Reading whether for pleasure or for academic purpose is an essential; habit that forms the bedrock of human greatness, gender or status. A reading nation is an informed nation (Onyenachi, 2016) [3]. Creative and critical thinking generate love for extensive reading. Onukaogu and Moh (2008) [4] report that:

Available research evidence shows that if the generality of people in a nation can be empowered to disseminate information amongst themselves, if they have the ability to effectively and efficiently manage and renew their human and natural resources; if they all collaborate in the total promotion of the economic and trade policies of their government and if they all promote the art of good governance, it would be relatively easy for such people to attain sustainable development. e must allow this pearl-reading. If we are to live meaningfully and not just exist as people.

Developed countries were able to attain their height because, at a point in their history, they were able to give themselves to much reading and research. Countries like Japan, America and Britain took to reading and research to achieve technological breakthrough (Uwa, 2013) [5]. If developing countries can re-orientate their citizens to have a change of attitude towards reading as well as 
research one can be rest assured that it will be just a matter of time for the dividend of an informed people to manifest in such countries (Gbadomosi; 2014) [6].

Reading builds career and talent. An academic reads. Learning is not attained by chance. Reading is a principal tool for academic, economic and socio political success in the modern society. It allows one to build knowledge, acquire information for accomplishment of goals and to derive pleasure from words (Osuigwe, Osuchukwu, Udeze and Jiagbogu, 2013 [7]). Reading plays critical roles in learning and inculcation of literacy. It is a foundational skill every human being needs to acquire early in life for equipping one for future responsibilities and academic achievement.

Maxwell (1998) [8], recalls President Theodore Roosevelt's words thus:“As a child I was nervous and timid, yet from reading of the people I admired... and knowing my father, I had a great admiration for men who were fearless and who could hold their own in the world and I had a great desire to be like them" (p. 40). Maxwell points out that by the time President Theodore Roosevelt graduated from Harvard, he was like those men he admired and he was ready to tackle the world politics. According to Maxwell, when President Theodore Roosevelt died in his sleep on January $6^{\text {th }} 1919$, when they removed him from his bed, they found a book under his pillow. Up to the very last, President Theodore Roosevelt, was still striving to learn and improve himself.

Leaders are readers, reading develops a man. A learner is a reader and a reader is a learner. According to Onukaogu and Moh (2008), in the modern school, efficient reading is the most important avenue to effective learning. Reading is so interrelated with the total educational process that educational process requires successful reading. They maintain that "experience has taught us that those who failed in school usually have failed in reading". Onukaogu and Moh citing Giordano Bruno said that "if the first button of a man's coat is wrongly buttoned all the rest are certain to be crooked. Reading is that first button in the garment of education. Reading impaired children tend to have difficulties in the learning in later years as the switch is made from learning to read to reading to learn. Reading difficulties deter academic progress. Whether print or electronic document reading is reading the difference is mastery of the skill in reading from a format either print or electronic. However reading requires alphabetical knowledge, phoneme awareness, phonics reading fluency, vocabulary and comprehensive skill. It involves a complex set of processes-physical, neurological and cognitive which are set in motion once a word is seen. These apply to the print and non-print document. Osuigwe et al. (2013). They state that:

In order to read, nerve impulses from the eyes stimulate the brain and this allows one to see the light and dark areas on a page that define each word. The brain then allows one to convert the letters into sound and these sounds into languages. Reading as an activity therefore requires the integration of several interlocking skills and abilities that enables one to convert 
document into meaning (p. 68).

Comprehension of the written language print or non print is the immediate goal of reading. Reading is essential in literacy and it is an emancipatory tool that liberates one from ignorance, disease and poverty as well as providing one with the liberty for all round development. For effective and efficient living and learning, Adeboye (2013) [9] maintains that one should be able to read. Reading is the foundation of literacy, hence reading culture is essential.

Lack of opportunity, incorrect and/or insufficient instruction, cultural factors and chaotic or impoverished living conditions can make a person to develop difficulties in reading. Osuigwe et al. (2013) points out that:

With the passage of the time the consequences of reading difficulties mount in a child and he may experience reduced opportunity for vocabulary growth, practice in reading than other children received lead to negative attitude towards reading. Consequently early detection of reading difficulties in children is a key to remedy and prevent the later academic pitfalls (p. 68).

\section{Whither reading culture in twenty first century Nigeria?}

We acclaim Nigerians don't have reading culture. Why? Only the literate reads. Literacy is the ability to read and write. Akali (2018) [10] reveal UNESCO survey September $13^{\text {th }}$ (2014) “The giant of Africa and her 35 million illiterate adults" Vanguardngr.com/2015/65-million-nigerians-are-illiterates/unesco/ and that illiteracy will never be overcome while 10 million Nigerian children remain out of school. The Federal Government of Nigeria on Thursday September $21^{\text {st }}$ (2017) described the illiteracy in the country as alarming. Nigerians that are literate read but reading culture is beyond purposeful reading just to get immediate knowledge at any given time. Reading culture is a habit. One can liken reading culture as addiction in reading. A person that has reading culture can be said to have reading addict. The languages and literature taught in primary and secondary schools as well as the profession librarianship strive to inculcate reading culture to Nigerians. Former Nigerian president Goodluck E. Jonathan lunched "bring back the book" in 2010. National Library of Nigeria in May/June 2017 organized reading competition still targeted to inculcating reading culture as to achieve lifelong learning in Nigerian children. Have these yielded any dividend? Consistency has positive outcome, National Library has follow up to the same programme by May 2018.

Reading campaign is a contemporary global trend to ensure the eradication of illiteracy across the globe, to ensure a stable maintenance of reading culture, to boost individual interest in reading, with the aim that respective readers would benefit immensely from the hidden virtues on the pages of the book that could be disclosed through reading. The culture of reading should be encouraged right from childhood. Reading empowers the reader mentally to be positive. Majority of the people at the grass root have been kept underdeveloped because of their low level of illiteracy. They have not been prepared for any creative, discrimina- 
tory process of reasoning. All these have adverse effect not only on the individual concerned but also on the political and economic situation of the country at large. It has also kept the majority of the people in the grass root below the bottom line of poverty.

Observation cries out that the e-technology has rather birthed and nourished viewing against reading. $21^{\text {st }}$ century generation with the computers, iPhones, iPad's, social media, internet etc. have enabled even nursery school children a level of proficiency in electronic usage. Have these impacted in lifelong learning? Curiosity has unlocked technology usage to Nigerian children it fevours viewing than reading.

According to Easier, Fryling, Peau and Macleod (1989) [11] "we live in a visually oriented society. Most people under thirty grew up watching television. We are accustomed to seeing and relating to stories and pictures. Stories help to think and process the message". After viewing? Information will still be documented in longhand print or electronic. Everything can never be visual format. Even visual medium do require explanation in long hand. It is he who can read that will have edge over one who cannot read. The brain skill of viewing and reading will definitely result to better understanding and knowledge application.

Reading materials today comprises of print and non-print. Guess many agree that curiosity favours electronic reading more than print. With the rate of acceptance of electronic over print can same curiosity recover print as to build reading culture and achieve long life learning?

\section{Curiosity key to reading culture and Lifelong learning}

Curious person asks, reads, views, and applies knowledge gained. In library profession, the lifelong learning and reading culture we emphasize can't work except one has curios mind and enjoy what he/she is reading/viewing and so learning.

According to Maxwell (2012) [12] growth is stimulated by asking why? $\mathrm{Cu}$ riosity will lead you to collect quotes, stories and ideas. Next you ask these collection why are they interesting? Why were they cute? Why did people laugh at them? Why were they innovation? Why did people connect with them? The essence of the collection is using the same kind of slant to make your own ideas creative and memorable. This will stimulate your growth and development. Maxwell says:

I believe curiosity is a key to being a lifelong learner, and if you want to keep growing and developing, you must keep on learning. Curious people possess a thirst for knowledge, they are interested in life, people, ideas, experiences and events and they live in a constant state waiting to learn more. They continually ask why? Curiosity is the primary catalyst for self-motivated learning. People who remain curious don't need to be encouraged to ask question or explore. They just do it all the time. And they just keep doing it. They know that the trail to discover is just as exciting as the discoveries themselves because there are wonderful things to be learned along the way. Curiosity helps a person to think 
and expand possibilities beyond the ordinary. Asking why fires the imagination. It leads to discovery. It opens up options. It takes people beyond the ordinary and leads to living extraordinary living. Curious people can learn, grow, and change. You do it intentionally. Knowledge, understanding and wisdom will not seek you out you must go out and acquire them. The best way to do that is to remain curious. Wonder why? Ask a lot of questions until you get answer.

Maxwell cites Management expert Peter Drucker who said "my greatest strength as a consultant is to be ignorant and ask a few questions".

Maxwell (2012) says anytime a person is answering, you can be sure they've slowed down in the growth and have lost the fire for personal growth. Growing leaders focus on asking questions not giving answers. Be a questioning machine. Make it a compulsion to pick the brains of people you meet. According to Maxwell, speaker and author Brain Tracy say's “A major stimulant to creative thinking is focused question". There is something about a well worded question that often penetrates to the heart of the matter and triggers new ideas and insight. Most of the time, focused question begins with the word why? Curious people ask the question to find solutions so they keep moving forward and making progress.

Ask why? Explore. Evaluate what you discover. Repeat. That's a pretty good formula for growth. One of the best ways to remain curious is to begin each day with determination to learn something different, or meet someone you don't already know. Have the mind set of reflection it does little good to see something new without taking time to think about it. It does no good to hear something new without applying it. The best way to learn something new is to take time at the end of the day to ask yourself a question that prompts you to think about what you have learned. Review your day and pull out the highlights. The best way to make a sluggish mind active is to disturb its routine.

According to Smith (2003) [13] firstly curiosity is itself a marker of intelligence secondly and more importantly, the habits of curiosity, exploration and learning, make for a knowledgeable person with perennially up-to-date skills. The person of lively and omnivorous interests is always a more successful professional. Creative and active intelligence is indispensable in lifelong learning and application. Such makes connection between one topic and another. They can rephrase questions in ways that invite new perspectives. It's not all a matter of knowing how or where to search for something. Often enough, it's a matter of knowing what else to explore. ("You should also try...").

In this regard, the role of intellect, knowledge and creativity are tremendously important, with these man controls technology not technology controlling man or replacing man (pp. 13-14).

Curiosity is important because curious people are constantly adding to their knowledge base. Curiosity reflects intelligence. It reflects the values and habits of learning.

Role of school library in student's reading 
1) The school library is acknowledged as a necessary adjunct to education as it is meant to help children develop good reading habit through the provision of wide reading materials and conducive environment for reading. School libraries stocked and organized with relevant materials for the students as well as equipped laboratories with staff competent to train the students enhances reading and reading culture (Farrant in Awa 2017). The library stock should have varied collection of enjoyable and information rich books that support the school curricula as well as general life development. Availability and accessibility of instructional and pleasurable books in library stimulate development of reading and attainment of permanent literacy. According to Gorman, and Clayton, (2005) [14] the library is an important source of knowledge to young minds in schools, its specific role(s) is to develop the habit of reading among the students, and help to impact positively on the academic advancement of the students. The school library also plays a vibrant role in the development of a culture that promotes wider reading, motivated readers and learners and learners for life. Furthermore, it promotes a place or collaborative learning, creating and developing independent research and information literacy skills.

2) The National Implementation Committee on Readership Promotion Campaigns, inaugurated by National Library Board in 1980 is targeted at young people and new literates and at correcting the poor functional approach to reading. Libraries in primary schools lay the foundation of habits at the formative stage of the pupil's education. Reading skill should be developed and sustained by reading materials. Aguolu and Aguolu in Onyenachi (2016), “children mature at different rates, are motivated to learn via different pressures and reach school with different intellectual equipment and backgrounds of experience”. Furthermore, the older the child gets, the more he differs from his class mate in terms of interests and goals of life. These go a long way to determine the kinds of reading habit the individual may form.

In this information age ( $21^{\text {st }}$ century), educational emphasis is shifting from the teacher centered to student centered learning and as children come to school from various socio economic strata (from well-to-do and poor, educated and illiterates families, and with different intellectual and cultural background), the need for individualization of learning has become imperative. Children from illiterate and lower social strata are not as motivated to read or interested in reading as those from educated families with good socio-economic backgrounds. The role of books and reading in school is influenced by such factors as competence and interest of the teachers and librarians in developing the reading habit of the children; provision of a dynamic school library service; and availability of books for purchase by the children for personal reading outside the school library.

School library encourages voluntary reading in students. The voluntary reading enables students to consult books to find out things on their own. This leads to self-development through self-research and it makes the students associate books (print and non-print) with pleasure and usefulness. Reading encompasses school purpose, leisure and quest for individualized development. 


\section{Linking reading to economic development}

Achieving quality education for all is one of the signs of a sustainable economy yet in Nigeria, just a little above half of the adult population is literate (about $57 \%$ ) whilst youth literacy is less than 70\% (UNESCO 2006). Between states, regions and gender, literacy rates vary also. An in-depth survey by the National Bureau of Statistics shows that Imo and Lagos states records the highest number of English literate adults at $80.8 \%$ and $80.5 \%$ respectively whilst Sokoto state has only $22.1 \%$ of its adult population literate in English language. Furthermore, urban literacy surpasses rural at a huge ratio of $69.4 \%$ to $38.5 \%$ whilst $65.1 \%$ of males are literate as opposed to $50.6 \%$ of females (National Literacy Survey (2010). This estimate reveals that about 65 million Nigeria still remain literate Akali (2018). Of the literate figure, reports have it that only a few are competent for employment. For instance, the small and medium Enterprises Development Agency of Nigeria (SMEDAN) reports that only about one of 100 graduates is employable.

The death of proactive and intuitive young people being churned out of Nigeria institutions today has been linked in part of a poor reading culture and habit developed from school. However, there is only so much that can be done to develop the reading habit in an adult if this habit had not been impressed upon such at an early age. Scholars have described reading as an art, a thorough process that entails complexity in thought and the ability to interpret, comprehend and communicate a message meaningfully. Going by this description, developing a reading habit is a delicate process that should be nurtured from the early stages of life and should involve not only the academic institutions, but also the home, the community and the larger society, if the quality of citizens and leaders in the society is to improve.

According to a survey by the world Culture Score Index on the average time people from different regions spend reading books per day, Indian was ranked the highest with an average of 10.7 hours/week, closely followed by Thailand and china with 9.4 and 8 hours reading time in a day. In Africa, only two countries were listed in the survey-Egypt and south Africa, with no mention of Nigeria.

As expected, there is a direct correlation between the quality of citizens and economic growth/development and a country's economic development is usually indicated by an increase in citizens' quality of life. Quality of life measured using the Human Development Index-takes to account intrinsic personal factors not considered in economic growth, such as literacy rates. Life expectancy and poverty, If a high literacy and in extension, good quality of life indicates economic development then, economic development can be triggered by having a society largely literate citizens which good reading habits contribute to.

According to Warren, (2018) [15] in commemoration of the 70th anniversary of the Universal Declaration of Human Rights, the United Nations Educational Scientific and Cultural Organization (UNESCO) has declared Monday, 23rd April 2018 World Book and Copyright Day with the theme "Reading it's my 
right". In ensuring that Nigeria achieves inclusive and quality education and promote lifelong learning as envisaged by the UN SDG4, the basic literacy skills currently demonstrated by the average young person needs to experience tremendous improvements. For this to be successfully attained, more attention has to be paid in grooming the reading capacity in young people.

\section{Increasing chances for improved education}

In order to increase the education figures in Nigeria: reduce illiteracy rates, increase the number of youth and adults with relevant skills for decent jobs and entrepreneurship, and position the country for sustainable development, it is expedient that proactive measures are made to advocate and promote national readership in Nigeria. The private sector is highly instrumental to achieving this fit (Warren, (2018)).

Supporting and equipping existing libraries: one of the means of implementation prescribed for SDG4 (4.a) is by providing effective learning environments; building and upgrading education facilities. However, this cannot be solely provided by the government.

Libraries are an important aspect of promoting the reading culture of people both schools and public libraries have experienced gross neglect over the years; they are inadequately funded and lack relevant reading resources to positively impact the public.

Organizations and individual that works towards re-establishing the libraries, providing books and reading materials to these libraries will be taking a significant step in not only reviving the reading culture in Nigerians but also increasing the literacy levels in young people and positioning the country for the achievement of SDG4 as well as the Sustainable Development Goals as a whole. Moreover, investment in education is capable of yielding direct return to a private sector investor through the integration of educationally empowered and competent youths into its workforce for better delivery and business growth.

Investing in activities and competitions that encourage reading: In order to create a lifelong reading culture and the requisite literacy expertise to excel in life, both children and young people need to regularly experience the enjoyment of reading by participating in local, regional and national prize competitions to stimulate strong peer-to-peer bonding elements and boost overall confidence in young people. This in turn will impact on their employability skills in the future. Both the Government, Private Organizations and Local/International NGOs have major roles in driving such competitions. Already, a couple of organizations have initiated activities that build the reading culture in young people through competitions; an example is the Lafarge Africa National Literacy competition, the Cowbell Mathematics competition, to mention a few (Warren, (2018)).

\section{Digitising book publications and libraries}

In order to revive the wanting interest in consuming relevant literature and improve Nigeria's education system, the reading format and presentation may very well need to change to recapture and revitalize the dying art. In retrospect, 
it may very well be the case that the reading culture is dying for the average $\mathrm{Ni}$ geria because reading has not been presented as a trendy and relevant habit to pick up. Indirect surveys indicate that for most Nigerians, the highest contact with books or any kind of intense reading is usually for the purpose of examination. Recent reports also claims that $40 \%$ of adults in Nigeria never get to finish any piece of non-fiction literature after they finish their education. This signifies the need to re-think the means of presenting reading to average Nigerians (Warren, (2018)).

In keeping with the growing digital trends, publishers and authors of books may do well to integrate some multi-media activities in the publication of books and even expand the scope of services to include online services in both school and public libraries. Through some of these activities like photography, digital printing \drawings, 3D, digital art and online services, studies have proven that digital natives (millennial) have been seen to display increased cognitive abilities. This presents another area of educational investment for the private sector.

Beyond directly investing in digital education, private organizations can also improve the reading habits of adults by digitizing corporate reports and manuals of products, to attract and ensure easy comprehension for their stake holders. This will in turn make this communications more effective.

\section{Dedicating spaces and resources to reading sessions and discussions}

As a way of lending support to the improve education cause and attracting economic growth for both the business and the country as a whole, organization can consider the dedication of corporate spaces to discussions and reading sessions, as well as educational workshops that can feature participation from children and young adults. Finally, encouraging the development of literacy meetings and other cultural events are other sure ways to equipping and encouraging heightened interest among Nigerians. Although the decision by the UNESCO in 1995 to recognize World Book and Copyright Day every year was essentially to pay global tribute to books and authors, annual commemoration of the day has evolved to become a means of stimulating more investments in reading for socio-economic development. It therefore behooves all sectors, especially the private, to place more interest and commitment to achieving this aim (Warren, 2018).

\section{Methodology}

The research design used in this study is descriptive survey. The population is from the senior secondary students one 225 and two 205 respectively total 430. Sample size of 172 was drawn using random sampling method. Nwana (2005) in Awa (2017) asserts that if population is above $200,40 \%$ of the population should be sampled to make up the sample for the study.

\section{Presentation of Results}

Out of 172 copies of questionnaires administered 164 copies returned which represent $95.3 \%$ return rate. The result was analyzed using simple percentage. 


\section{Response rate}

A total number of 172 questionnaires were administered out of which, 164 (95.3\%) were retrieved and found useful for analysis.

From Table 1 shows that 172 questionnaires was administered, 164 (95.3) were retrieved out of which 86 (57.9) was from SSS1, while 78 (42.1\%) was from SSS2 students of Ibeku high school.

Research question 1: Which of these reading materials are students in your school exposed to?

Note: $\mathrm{SA}=$ strongly agreed, $\mathrm{A}=$ agreed, $\mathrm{D}=$ disagreed, $\mathrm{SD}=$ strongly disagreed.

Table 2 reveals the response on reading material in Ibeku high school. The result shows that school text books had response rate of 56 (34.1\%) for strongly agree, 108 (65.9\%) agreed, none for disagreed and strongly disagreed. Magazine had response rate of 4 (2.4) for strongly agreed, 8 (4.9\%) agreed, $143(87.2 \%)$ disagreed and 9 (5.5\%) strongly disagreed. For newspapers had response 16 (9.8\%) strongly disagreed. Electronic information materials had 4 (2.4\%) for strongly agreed, $11(6.7 \%)$ agreed, 133 (81.1\%) disagreed and $16(9.8 \%)$ strongly agreed. Other informative books had response rate of 8 (4.9\%), 27 (16.5\%) agreed, 122 (74.4\%) strongly disagreed and 7 (4.3\%) strongly disagreed.

Question 2: What are the students reasons for reading?

Table 3 presents responses from respondents on their reasons reading The result shows that to develop communication skill had response rate of 37 (22.6\%) strongly agreed, 116 (70.7\%) agreed, 10 (6.1\%) disagreed and 1 (0.6) strongly disagreed. Personal research for self development had response rate of

Table 1. Questionnaire administered and rate of return.

\begin{tabular}{cccc}
\hline Name of school/class distribution & $\begin{array}{c}\text { Copies of number } \\
\text { of questionnaire } \\
\text { administered }\end{array}$ & $\begin{array}{c}\text { Number of copies } \\
\text { of questionnaire } \\
\text { returned }\end{array}$ & $\begin{array}{c}\text { Percentage } \\
(\%)\end{array}$ \\
\hline SSS1 class of Ibeku high school & 90 & 86 & $57.9 \%$ \\
SSS2 class of Ibeku high school & 82 & 78 & $42.1 \%$ \\
TOTAL & 172 & 164 & $100 \%$
\end{tabular}

Source: Research questionnaire administered 2017.

Table 2. Reading material in Ibeku high schools.

\begin{tabular}{|c|c|c|c|c|c|c|c|c|c|}
\hline$s / n$ & ITEMS & SA & $\%$ & A & $\%$ & $\mathrm{D}$ & $\%$ & SD & $\%$ \\
\hline 1 & School text books & 56 & 34.1 & 108 & 65.9 & - & - & - & - \\
\hline 2 & Magazine & 4 & 2.4 & 8 & 4.9 & 143 & 87.2 & 9 & 5.5 \\
\hline 3 & Newspapers & 1 & 0.6 & 8 & 4.9 & 139 & 84.8 & 16 & 9.8 \\
\hline 4 & Electronic information materials & 4 & 2.4 & 11 & 6.7 & 133 & 81.1 & 16 & 9.8 \\
\hline 5 & Other information book & 8 & 4.9 & 27 & 16.5 & 122 & 74.4 & 7 & 4.3 \\
\hline
\end{tabular}

Source: Research questionnaire administered 2017. 
$33(20.1 \%)$ strongly agreed, 104 (63.4\%) agreed, 26 (15.9\%) disagreed and 1 $(0.6 \%)$ strongly agreed. To pass examination had response rate of $73(44.5 \%)$ strongly agreed, $85(51.8 \%)$ agreed, $4(2.4 \%)$ disagreed and $2(1.2 \%)$. Finally, to avoid being punished by parents had response rate of $10(6.1 \%)$ strongly agreed, 41 (25.0\%) agreed, 104 (63.4\%) disagreed and 9 (5.5\%) strongly disagreed.

Research question 3: Which of the following might be challenges to students' reading?

This Table 4 presents responses on the challenges to reading the result shows that lack of personal reading materials had responses rate of $53(32.3 \%)$ for strongly agreed, $103(62.8 \%)$ agreed, 7 (4.3\%) disagreed and 1 (0.6\%) strongly disagreed. Absence of equipped school library had response rate of $25(15.2 \%)$ strongly agreed, 87 (53.0\%) agreed, 51 (31.1\%) disagreed and $1(0.6 \%)$ strongly disagreed. Peer group discouragement had response rate of $60(36.6 \%)$ strongly disagreed. Preference to viewing than reading had response rate of $51(31.1 \%)$ strongly agreed, 109 (66.5\%), 3 (1.8\%) disagreed and 1 (0.6\%) strongly disagreed. Finally, no encouragement from family had response rate of 35 (21.3\%) for strongly agreed, 106 (64.6\%) agreed, 18 (11.0\%) disagreed and 5 (3.0\%) strongly disagreed.

Research question 4: Which of the following are solutions to poor reading culture in your school?

Table 5 reveals responses from respondents on the solutions to the challenges of reading. The result shows that provision of furnished school library had response rate of 67 (40.9\%) strongly agreed, none for disagreed and strongly disagreed. Support from parents and teachers had 74 (45\%) strongly agreed, 90 (54.9\%) agreed none for disagreed and strongly disagreed. Developing personal varied collection had response rate of 63 (38.4\%) for strongly agreed, 95 (57.9\%) agreed, none disagreed and $3(1.8 \%)$ strongly disagreed. Avoidance of viewing

Table 3. Reasons for reading.

\begin{tabular}{|c|c|c|c|c|c|c|c|c|c|}
\hline $\mathrm{S} / \mathrm{N}$ & ITEM & SA & $\%$ & A & $\%$ & $\mathrm{D}$ & $\%$ & $\mathrm{SD}$ & $\%$ \\
\hline 1 & To develop communication skills & 37 & 22.6 & 116 & 70.7 & 10 & 6.1 & 1 & 0.6 \\
\hline 2 & Personal research for self development & 33 & 20.1 & 104 & 63.4 & 26 & 15.9 & 1 & 0.6 \\
\hline 3 & To pass examination & 73 & 44.5 & 85 & 51.8 & 4 & 2.4 & 2 & 1.2 \\
\hline 4 & To avoid being punished by parents & 10 & 6.1 & 41 & 25.0 & 104 & 63.4 & 9 & 5.5 \\
\hline
\end{tabular}

Source: Research questionnaire administered 2017.

Table 4. Challenges to students' reading.

\begin{tabular}{cccccccccc}
\hline S/N & ITEMS & SA & $\%$ & $\mathrm{~A}$ & $\%$ & $\mathrm{D}$ & $\%$ & $\mathrm{SD}$ & $\%$ \\
\hline 1 & Lack of personal reading materials & 53 & 32.3 & 103 & 62.8 & 7 & 4.3 & 1 & 0.6 \\
2 & Absence of equipped school library & 25 & 15.2 & 87 & 53.0 & 51 & 31.1 & 1 & 0.6 \\
3 & Peer group discouragement & 60 & 36.6 & 98 & 59.8 & 6 & 3.7 & - & - \\
4 & Preference to viewing than reading & 51 & 31.1 & 109 & 66.5 & 3 & 1.8 & 1 & 0.6 \\
5 & No encouragement from family & 35 & 21.3 & 106 & 64.6 & 18 & 11.0 & 5 & 3.0 \\
\hline
\end{tabular}

Source: Research questionnaire administered 2017. 
Table 5. Solution to poor reading culture in Ibeku high school.

\begin{tabular}{|c|c|c|c|c|c|c|c|c|c|}
\hline $\mathbf{S} / \mathbf{N}$ & ITEMS & SA & $\%$ & A & $\%$ & $\mathrm{D}$ & $\%$ & SD & $\%$ \\
\hline 1 & Provision of furnished school library & 67 & 40.9 & 96 & 58.5 & 1 & 0.6 & - & - \\
\hline 2 & Support from both parents and teachers & 74 & 45.1 & 90 & 54.9 & - & - & - & - \\
\hline 3 & Developing personal varied collection & 63 & 38.4 & 95 & 57.9 & 4 & 2.4 & 2 & 1.2 \\
\hline 4 & Avoidance of viewing distraction & 67 & 40.9 & 94 & 57.3 & - & - & 3 & 1.8 \\
\hline 5 & Avoidance of peer group distraction & 71 & 43.3 & 91 & 55.5 & - & - & 2 & 1.2 \\
\hline
\end{tabular}

Source: Research questionnaire administered 2017.

distraction had 67 (40.9\%) strongly agreed, 94 (57.3\%) agreed, none for disagreed while 3 (1\%) strongly disagreed. Finally, avoidance of peer group distraction had response rate of 71 (43.3\%) for strongly agreed, 91 (55.5\%) agreed, none disagreed and $2(1.2 \%)$ strongly disagreed.

\section{Conclusion}

From the research findings students reading for self development limiting to school subjects is not possible. Many responses indicate that they do not have personal reading materials (32.3\%) for strongly agreed, 103 (62.8\%) agreed.

\section{Recommendations}

1) The government being owner of public school should be committed in funding the school library as well as directly sending print and non print information materials to schools. Teaching and Learning are not done in a vacuum.

2) School Principals and teachers should not be less concerned in equipping the school library. They should make the government realize the need for learning materials which is not only text books. This will convince the government to adequately fund the school library for collection development.

3) School administrators should solicit for assistance from parents through the parent teacher forum.

4) The school administrators should as well contact donors to assist.

5) Public libraries by their mandate caters for the information need of the entire citizen to which secondary school teachers and students are among. The school administrators should contact the public library to come to their aid.

\section{Suggestions for Further Study}

Based on these findings, the following are made for further studies or research.

1) School libraries and development of reading culture among primary school pupils in Abia State.

2) Nigeria School libraries and development of reading culture among secondary school students in Abia State Nigeria.

3) School librarian's Association and school library development for lifelong reading in Nigeria. 
4) Ministries of education implementation of National policy on education in school libraries: case of public schools in Abia State Nigeria.

\section{Conflicts of Interest}

The authors declare no conflicts of interest regarding the publication of this paper.

\section{References}

[1] Awa, O.O. (2017) Reading Culture and Academic Performance among Government Secondary School Students in Abia State: A Case of Ibeku High School Umuahia. Unpublished BLIS Project Michael Okpara University of Agriculture Umudike.

[2] Tella, A. and Akande, S. (2007) Children's Reading Habit and Availability of Books in Botswana Primary School: Implication for Achieving Quality Education. The Reading Matrix. Library Philosophy and Practice.

[3] Onyenachi, J.C. (2016) Bring Back the User. JopFlows Publishers, Umuahia.

[4] Onukaogu, C.E. and Moh, F. (2008) Let's Appropriate the Pearls in Reading that We May Live and Not Barely Exist. In: Emejulu, O.A., Uwatt, L.E. and Arua, A.E., Eds., Topical Issues in Literacy, Language and Development in Nigeria, International Development in African Committee Reading Association of Nigeria, Newwark.

[5] Uwa, E.O. (2013) Reading Culture of Students in Three Selected Tertiary Institutions in Imo State Heartland. Journal of Library and Information Science, 1.

[6] Gbadamosi, T. (2014) Library Reading Culture and Student's Academic Performance in Secondary Schools in Oyo State. Middlebelt Journal of Library and Information Science, 7.

[7] Osuigwe, N.E., Osuchukwu, N.P., Udeze, N.S. and Jiagbogu, C.O. (2013) Framework for Inculcation of Reading Skills in Children with Reading Difficulties. Nigerian Libraries. Journal of the Nigerian Library Association, 46.

[8] Maxwell, J.C. (1998) The 21 Irrefutable Laws of Leadership. In: Ultimate Leadership: Maximize Your Potential and Empower Your Team, U.S.A Maxwell Motivation, Inc.

[9] Adeboye, O. (2013) Reading Culture of Secondary School Teachers: A Study of Selected Secondary Schools in Ado Edo L.G.A Edo State. Library Philosophy and Practice, 1.

[10] Akali, M. (2018) 65 Nigerians are illiterates-UNESCO. https://www.vanguardngr.com/2015/65-million-nigerians-are-illiterares-unesco/

[11] Easier, J.M., Frying, A., Peau, P.L. and MacLeod, M. (1989) Disciplemakers Handbook. U.S.A. Inter Varsity Press.

[12] Maxwell, J.C. (2012) The 15 Invaluable Laws of Growth: Live Them and Reach Your Potential. Center Street, New York.

[13] Smith, K.A. (2003) The Curious Librarian. In: Bridges, K., Ed., Expectation of Librarians in the 21 st Century, United States Greenwood Press.

[14] Gorman, G.E. and Clayton, P. (2005) Qualitative Research for the Information Professional: A Practical Hand Book. 2nd Edition, Facet Publishing, London, 2.

[15] Warren, B. (2018) Linking National Reading to Economic Development. Guardian, 20th April 2018, 32. 